\title{
Initial Sintering and Grain Growth Kinetics of Magnesium Oxide (MgO) Prepared by Alkoxy-Method
}

\author{
Osamu Yamaguchi**, Hitoshi Tonami**, \\ Tadahiro Hayashi**, Kiyoshi Shimizu**
}

\begin{abstract}
The kinetics of the initial sintering and grain growth of magnesium oxide ( $\mathrm{MgO}$ ) prepared by the alkoxy-method were investigated by means of dilatometry, electron microscopy and the measurement of isothermal shrinkage. The obtained results are summarized as follows.

(1) The initial sintering kinetics of $\mathrm{MgO}$ were determined from 1000 to $1200^{\circ} \mathrm{C}$. The sintering process was governed by the volume diffusion of oxygen ions which was represented by $D=2.54 \times 10^{-5} \exp (-64,000 /$ $R T) \mathrm{cm}^{2} / \mathrm{sec}$.

(2) The grain growth of $\mathrm{MgO}$ was represented by the expression of $G^{2}-G_{o}^{2}=k t$, and the temperature dependence of $k$ was given by $k=3.3 \times 10^{-3} \exp (-77,000 / R T) \mathrm{cm}^{2} / \mathrm{sec}$.
\end{abstract}

(Received November 5, 1976)

\section{Introduction}

It has previously been reported ${ }^{11}$ that the magnesium oxide ( $\left.\mathrm{MgO}\right)$ powder's prepared by the alkoxy-method were highly sinterable. This reason was explained as follows. The alcoholic hydrocarbon occluded in powders or free carbon produced by its decomposition may react with oxygen of $\mathrm{MgO}$ at the surface, resulting in the evolution of $\mathrm{CO}$ and/or $\mathrm{CO}_{2}$ and $\mathrm{H}_{2} \mathrm{O}$. As a result, many oxygen vacancies in non-equilibrium would be produced in the vicinity of grain boundary, and the sintering of $\mathrm{MgO}$ could be accelerated remarkably. The present investigation deals with the kinetics of the initial sintering and grain growth of $\mathrm{MgO}$ prepared from alkoxide.

\section{Experimental Procedure}

\section{II-1 Material}

The starting material was synthesized by heating magnesium foil of $99.9 \%$ purity in an excess

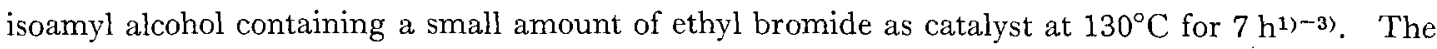
obtained magnesium isoamyloxide was hydrolyzed by pouring slowly into water at $90^{\circ} \mathrm{C}$. X-Ray diffraction patterns showed that the resulting product was $\mathrm{Mg}(\mathrm{OH})_{2}$. Thermal analysis of the powder at the heating rate of $10^{\circ} \mathrm{C} / \mathrm{min}$ showed that the dehydration was completed at $440^{\circ} \mathrm{C}$. Gradual weight loss of $3.45 \%$ was observed between 440 and $930^{\circ} \mathrm{C}$. This would be attributed to the liberation of alcoholic residue occluded in the derived powder. Loose $\mathrm{Mg}(\mathrm{OH})_{2}$ powders were calcined at $800^{\circ} \mathrm{C}$ for $2 \mathrm{~h}$. The average particle size determined from electron microscopic observation was $700 \AA$.

* Received November 5, 1976.

** Department of Applied Chemistry, Faculty of Engineering, Doshisha University, Kyoto 602. 


\section{II-2 Isothermal Shrinkage}

Compacts of $10 \mathrm{~mm}$ in diameter and about $1.5 \mathrm{~mm}$ in thickness were prepared at $3 \mathrm{ton} / \mathrm{cm}^{2}$ with distilled water as a binder. The pressed compacts were pre-heated at $200^{\circ} \mathrm{C}$ for $1 \mathrm{~h}$ to remove the binder. The density of the compacts was about $55 \%$ of the theoretical density. ${ }^{4)}$ Linear shrinkage measurement of the compact was carried out from room temperature to $1200^{\circ} \mathrm{C}$ in air at heating rate $200^{\circ} \mathrm{C} / \mathrm{h}$ prior to that of isothermal shrinkage. The shrinkage proceeded gradually from about $880^{\circ} \mathrm{C}$ and rapidly from $930^{\circ} \mathrm{C}$. On the basis of this result, isothermal shrinkage measurement was carried out in the temperature range between 1000 and $1200^{\circ} \mathrm{C}$ in air. It required about 30 seconds for the furnace to reach at a definite temperature. The furnace was controlled within $\pm 5^{\circ} \mathrm{C}$ by a program controller.

\section{II-3 Microscopic Observation}

The fractured surfaces of sintered compacts were prepared in order to examine grain growth. The average grain size, $D$, was calculated by the following equation, ${ }^{5}$

$$
\bar{D}=1.56 \frac{C}{M N}
$$

where $C$ is the total length of test line used, $N$ the number of intercepts, and $M$ the magnification of the photomicrograph. The constant, 1.56, is a correction factor which was derived by Mendelson. ${ }^{6}$

\section{Results and Discussion}

\section{III-1 Initial Sintering Mechanism}

The diffusion shrinkage equation ${ }^{\text {7)-9) }}{ }^{-9}$ for the initial sintering of the compact is:

$$
\left[\frac{\Delta L}{L_{0}}\right]=\left[\frac{K \gamma a^{3} D}{k T r^{p}}\right]^{m} t^{m}
$$

where $\Delta L / L_{0}=$ shrinkage rate, $k=$ the Boltzmann constant, $T=$ absolute temperature, $r=$ particle radius, $\gamma=$ surface energy, $a^{3}=$ vacancy volume, $D=$ diffusion coefficient for the rate controlling species, $t=$ time, and $K, m$ and $p$ are constants depending on mechanism.

According to Wermuch et al. ${ }^{10)}$ oxygen ions in grain-boundary diffusion are the rate controlling species for the initial sintering $\left(814-1060^{\circ} \mathrm{C}\right)$ of $\mathrm{MgO}$ and the value of the activation energy is 60.2 $\mathrm{kcal} / \mathrm{mol}$. On the other hand, Matuda et al. ${ }^{11)}$ have reported that the initial sintering process for obtaining the transparent $\mathrm{MgO}$ compact is governed by volume diffusion of oxygen ions and the activation energy is $55.8 \mathrm{kcal} / \mathrm{mol}$.

The results of isothermal shrinkage are plotted by the $\log \left(\Delta L / L_{0}\right)-\log t$ in Fig. 1 . The data showed straight lines with a slope of $0.49-0.50$. Therefore, the results suggest that the initial sintering process is governed by volume diffusion mechanism which can be represented by the following Coble's model. ${ }^{9}$

$$
\left[\frac{\Delta L}{L_{0}}\right]=\left[\frac{2 \gamma a^{3} D}{k T r^{3}}\right]^{0.5} t^{0.5}
$$

Figure 2 shows the diffusion coefficients calculated from Eq. (3) by assuming that the diffusion of the oxygen ion vacancy $\left(a^{3}=1.86 \times 10^{-23}\right)$ controls the rate. The values of $r$ and $\gamma$ used are $350 \AA$ and $1000 \mathrm{erg} / \mathrm{cm}^{2,9)}$ respectively. Consequently, the following equation was derived:

$$
D=2.54 \times 10^{-5} \exp (-64,000 / R T) \mathrm{cm}^{2} / \mathrm{sec}
$$




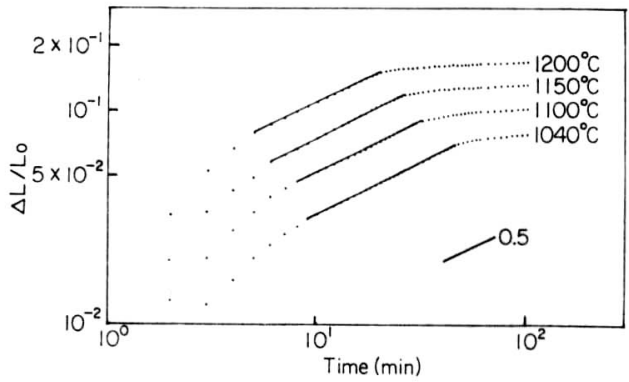

Fig. 1 Isothermal shrinkage of $\mathrm{MgO}$.

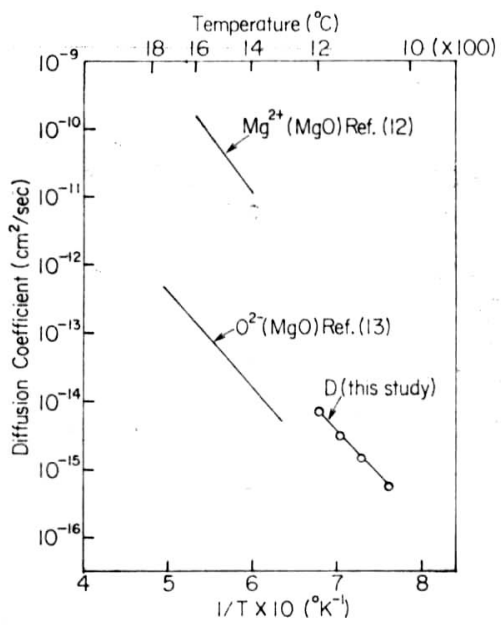

Fig. 2 Self-diffusion of ions in $\mathrm{MgO}$ and the diffusion coefficients from initial sintering of MgO.

The self diffusion data for $\mathrm{MgO}^{12), 13)}$ are also shown in Fig. 2. The activation energy in the present study is in good agreement with that $\left(62.4 \mathrm{kcal} / \mathrm{mol}^{13)}\right)$ for oxygen self diffusion in $\mathrm{MgO}$ in the extrinsic range. Therefore, this activation energy may refer to oxygen ion mobility. ${ }^{13)}$ From this fact, it was found that the initial sintering process of $\mathrm{MgO}$ prepared by the present method is governed by the volume diffusion of oxygen ions. However, oxygen diffusion coefficients are about one order of magnititude greater than those for oxygen self diffusion in $\mathrm{MgO}$. This seems because many oxygen vacancies in non-equilibrium produced in the vicinity of grain boundary as described earlier ${ }^{1)}$ promote the migration of oxygen ions. Therefore, so long as oxygen ions are the rate controlling species, the sintering of $\mathrm{MgO}$ could be accelerated.

\section{III-2 Grain Growth}

The $\mathrm{MgO}$ powder was prepared under the same condition as that in isothermal shrinkage. The pressed compacts were sintered between 1200 and $1400^{\circ} \mathrm{C}$. The relative density of the sintered compacts was in the range of 95.4 to $97.8 \%$. The densification at low temperatures in this way resulted in the sintered compacts consisting of fine grains. Photograph 1 shows the fracture surfaces of the compacts sintered at 1200,1300 and $1400^{\circ} \mathrm{C}$ for $3 \mathrm{~h}$. The rate of grain growth is represented by the following equation,

$$
G-G_{0}=k^{\prime} t^{l / n}
$$

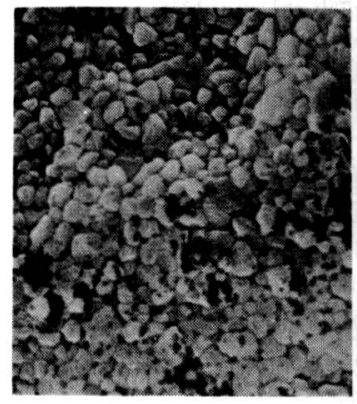

$1200^{\circ} \mathrm{C}, 3 \mathrm{~h}$

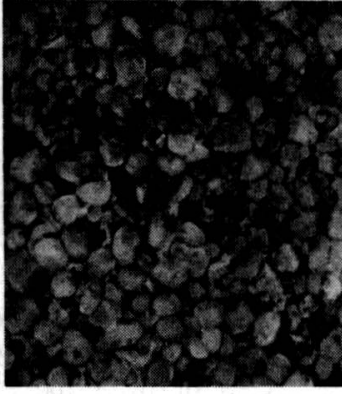

$1300^{\circ} \mathrm{C}, 3 \mathrm{~h}$

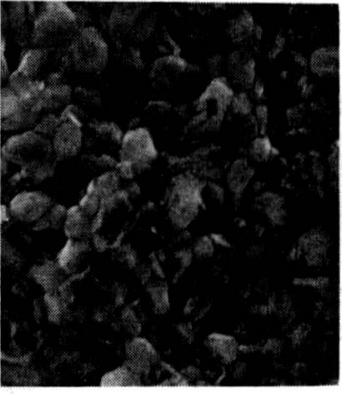

$1400^{\circ} \mathrm{C}, 3 \mathrm{~h}$

Photo. 1 Electron micrographs of the fractured surface of $\mathrm{MgO}$ sintered at various temperatures for $3 \mathrm{~h}$. 


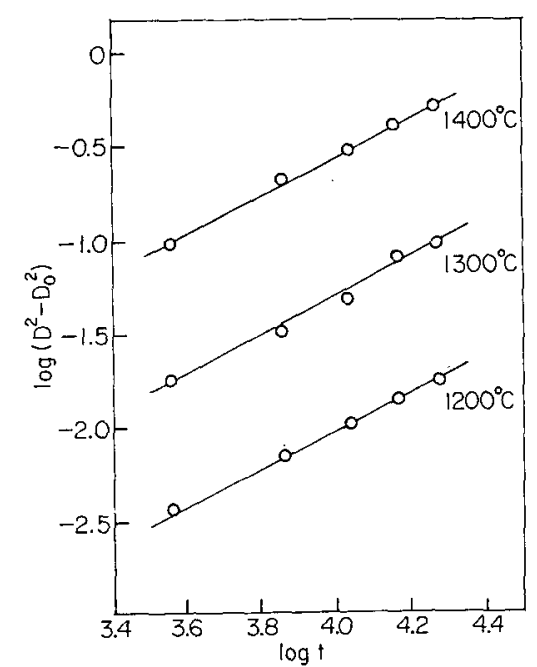

Fig. 3 Isothermal grain growth of $\mathrm{MgO}$.

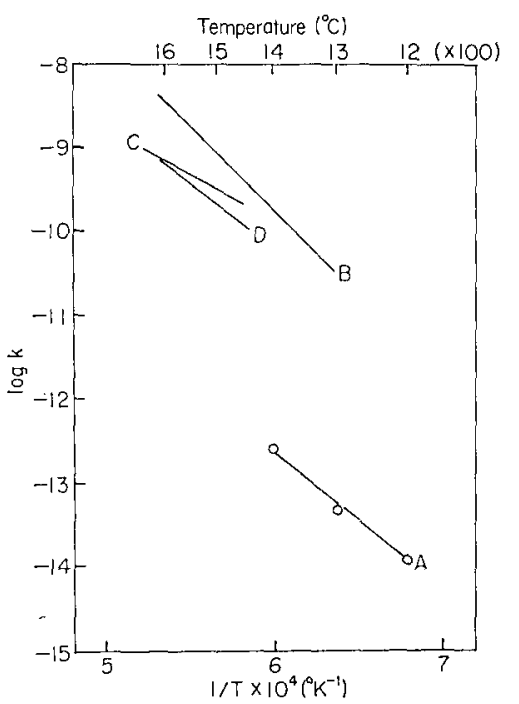

Fig. 4 Temperature dependences of the rate constants for the grain growth of $\mathrm{MgO}$.

A: Present study, B: Spriggs et al.
C: Daniels et al., D: Gupta

where $G$ is the grain size of the sintered compacts, $G_{0}$ the initial grain size, $t$ the time, $k$ ' the rate constant, and $n$ is usually $2^{14)}$ or $3^{15)}$ for the sintering of oxides in the absence of a liquid phase. To determine the relation of the grain size vs time, the measured grain size was plotted as a function of both the square root and the cubic root of time. The plot as the function of the square root of time gave a favorable linear relation. Therefore, the grain growth for $\mathrm{MgO}$ is given by the relation of $n=2$ in Eq. (5) as follows,

$$
G^{2}-G_{0}^{2}=k t
$$

Figure 3 shows the plots of $\log \left(G^{2}-G_{0}{ }^{2}\right)$ against $\log t$. The value of $G_{0}$ used is $700 \AA$. The rate constant for the grain growth was calculated at each temperature and the activation energy obtained from Arrhenius plot was the value of $77 \mathrm{kcal} / \mathrm{mol}$ (Fig. 4). The grain growth data gave the following expression for the temperature of $k$ :

$$
k=3.3 \times 10^{-3} \exp (-77,000 / R T) \mathrm{cm}^{2} / \mathrm{sec}
$$

The data for the grain growth reported by other investigators ${ }^{16)-18)}$ are also shown in Fig. 4. The relation of $n=2$ in Eq. (5) is applied to all the reports. The activation energy $(77 \mathrm{kcal} / \mathrm{mol})$ in the present study was nearly identical to that $\left(81 \mathrm{kcal} / \mathrm{mol}^{16)}, 75.5 \mathrm{kcal} / \mathrm{mol}^{17)}\right)$ obtained by Spriggs et al. ${ }^{16)}$ and Gupta. ${ }^{17)}$ However, the value of $k$ was about three orders of magnititude smaller than that of other data.

\section{References}

1) O. Yamaguchi, H. Tonami, K. Shimizu: Chemistry Lett., (1976), 799.

2) O. Yamaguchi, Y. Nakajima, K. Shimizu: Chemistry Lett., (1976), 401.

3) O. Yamaguchi; Y. Nakajima, K. Takeoka, K. Shimizu: J. Japan Powder and Powder Metallurgy, 23 (1976), 73.

4) For example, L. M. Atras: J. Am. Ceram. Soc., 40 (1957), 196.

5) J. C. Wurst, J. A. Nelson: J. Am. Ceram. Soc., 55 (1972), 102.

6) M. I. Mendelson: J. Am. Ceram. Soc., 52 (1969), 443. 
7) W. D. Kingery, M. Berg: J. Appl. Phys., 26 (1955), 1025.

8) D. L. Johnson, I. B. Cutler: J. Am. Ceram. Soc., 46 (1963), 541.

9) R. L. Coble: J. Am. Ceram. Soc., 41 (1958), 55.

10) F. R. Wermuch, W. J. Knapp: J. Am. Ceram. Soc., 56 (1973), 401.

11) S. Matuda, S. Shirasaki, Y. Komatu, T. Ikegami: presented at the 13th Symposium on the Basis of Ceramics, (1975), 29.

12) R. Linder, C. D. Parfit: J. Chem. Phys., 26 (1957), 182.

13) Y. Oishi, W. D. Kingery: J. Chem. Phys., 33 (1960), 905.

14) For example, W. D. Kingery: Introduction to Ceramics, John Wiley \& Sons, Inc., (1967), 359.

15) W. D. Kingery, B. Francois, J. Am. Ceram. Soc., 48 (1965), 546.

16) R. M. Spriggs, I. A. Britete, T. Vasilos: J. Am. Ceram. Soc., 47 (1964), 417.

17) T. K. Gupta: J. Materials Science, 6 (1971), 25.

18) A. U. Daniels, Jr., R. C. Lowie, Jr., R. L. Gibby, I. B. Cutler: J. Am. Ceram., 45 (1962), 282.

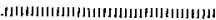

\section{本 会 記 事}

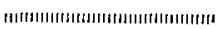

\section{第 115 回理 事 会議 事 録}

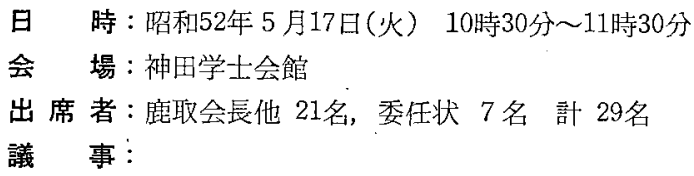

1. 昭和51年度事業報告，收支決算報告の件（承認）

2. 会計監查報告の件 （承認）

3 . 昭和 52 年度事業計画, 収支予算案の作 (承認)

4. 協会賞受賞候補者推驚委員選出の件 (承認)

5. 創立 20 周年記念事業の件

6. その他諸報告

1) 第 9 回粉末冶金入門講座開催の報告

2）第 7 回フェライト夏季セミナー開催の件

3）第15回粉体汇関する討論会共催の件

4）第16回窯業基礎討論会共催の件

5）日本工学会 創立 100 周年記念事業準借委員推薦 依頼の件

6）第 3 回国際フェライト会議の件

7) 特別会員脱会の件

8）金属研究連絡委員会及び金属関係10学協会連絡 委員会報告

\section{第 23 回評議員会議事録}

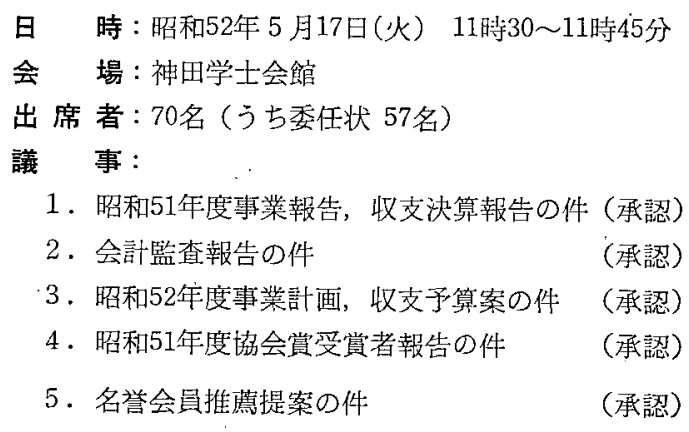

\section{第 23 回 総 会議 事 録}

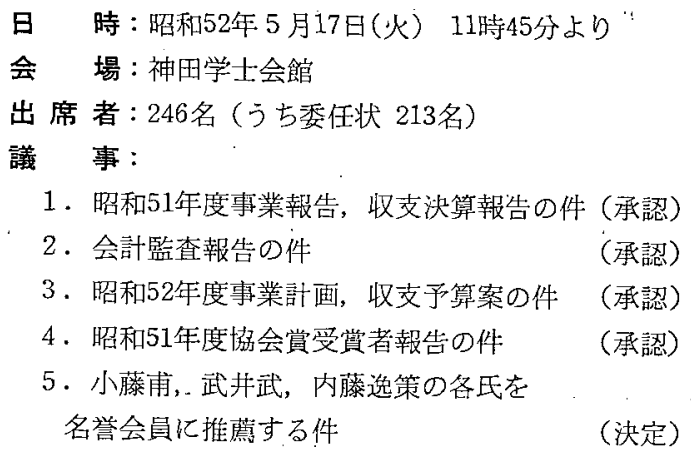

